\title{
After Liberal Hegemony: The Advent of a Multiplex World Order Amitav Acharya
}

he dominance of a single great power," wrote American scholar
Robert Keohane in his widely acclaimed book After Hegemony,
"may contribute to order in world politics, in particular circumstances, but it is not a sufficient condition and there is little reason to believe that it is necessary." ${ }^{1}$ This proposition has never been put to a greater test as it is now. Since the election of Donald J. Trump as U.S. president in November 2016 there has been a vast outpouring of anxiety over the future of the liberal world order. ${ }^{2}$ But the myths, limitations, and decline of this order have been anticipated and forewarned for some time, even though its proponents have not acknowledged it.

The "first myth" about the U.S.-led liberal hegemonic order, as I have written elsewhere, is "how far it extended for much of its history, especially during the Cold War period." I pointed out that "the Soviet bloc, China, India, Indonesia, and a good part of the 'third world' were outside of it . . . Despite the exalted claims about its power, legitimacy, and public goods functions, that order was little more than the US-UK-West Europe-Australasian configuration." ${ }^{3}$ Noting that the liberal order was hardly benign for many countries in the developing world, I argued that it should be seen as a limited international order, rather than an inclusive global order.

Joseph S. Nye, one of the staunchest champions of the liberal order, made a similar point when he wrote in the January/February 2017 issue of Foreign Affairs that the liberal order "was largely limited to a group of like-minded states centered on the Atlantic littoral" and "did not include many large countries such as China, India, and the Soviet bloc states, and . . . did not always have benign effects on nonmembers." 4 The liberal order did expand and strengthen with the

${ }^{\star}$ This essay is based on the second edition of the author's book The End of American World Order (forthcoming).

Ethics \& International Affairs, 31, no. 3 (2017), pp. 271-285.

(C) 2017 Carnegie Council for Ethics in International Affairs

doi:10.1017/So89267941700020X 
economic reforms in China and India, and with the end of the cold war. And while the champions of that order celebrated its expansion, they still generally assumed that the main challenge to it would come from the rising powers, led by China. Their assumptions notwithstanding, precisely at a time when many of these powers today are not doing all that well, the liberal order appears to be imploding. Trump's victory and Brexit suggest that the current challenge to the liberal order is as much, if not more, from within as from without.

The domestic challenges to the liberal order led by Trump and his supporters could be overstated, however. After all, Hillary Clinton won a majority of the popular vote, and the Brexit referendum only passed by a slim margin. More importantly, however, the crisis of the liberal order has deeper roots, owing to long-term and structural changes in the global economy and politics. As such, Trump's ascent to power is a consequence-not a cause-of the decline of the liberal order, especially of its failure to address the concerns of domestic constituents left behind by the global power shift. Given these factors, Trump is unlikely to reverse the decline of the liberal order even if he wanted to. Instead, he may well push it over the precipice.

In what follows, I first describe the foundations of the liberal order, and show that the ground on which it was built has been eroding for some time, though Trump's rhetoric and policies are also damaging. Next, I argue that for now the rising powers are not in a position to overturn the current order completely, and in fact they may wish to preserve some elements of it in the near and medium term. I describe a "multiplex world" in which elements of the liberal order survive, but are subsumed in a complex of multiple, crosscutting international orders. Finally, I offer some suggestions on how scholars and policymakers can manage the transition to such a multiplex world.

\section{Foundations of the Liberal Order}

The idea of liberal international order rests on four key elements: free trade; post-war multilateral institutions; the growth of democracy; and liberal values. As I will show, each of these elements has been stagnating and decaying for some time. Rather than being the cause of the stagnation, Trump is simply hastening the decay.

In recent decades China's phenomenal economic growth has been a major factor behind the expansion of global free trade. Since 2010, however, global trade has been growing at a meager annual rate of 2 percent and the trade-to-gross 
domestic product (GDP) ratio has been falling. ${ }^{5}$ Not coincidentally, this corresponds closely with China's recent economic slowdown. And this is not a temporary change. China's shift to a domestic consumption-driven economy and the likelihood of a middle-income $\operatorname{trap}^{6}$ could continue to have a negative impact on world trade for years to come, regardless of the policies President Trump may adopt toward China or on trade in general.

Add to this slowdown the sentiments against globalization in the United States, which we saw come to the fore in the 2016 presidential election. Those states that the Democratic candidate Hillary Clinton was expected to carry-such as Wisconsin (which had not voted for a Republican presidential candidate since 1984) and Pennsylvania and Michigan (which had not done so since 1988) - as well as such swing states as Ohio and North Carolina all voted for Trump because of disillusionment with economic globalization and free trade. ${ }^{7}$ Trump ran on an electoral platform that pledged to withdraw from the Trans-Pacific Partnership (which he has since done), to renegotiate or withdraw from NAFTA, and to punish China for its alleged currency manipulation, "theft of American trade secrets," and "unfair subsidy behavior."

The second key element of the foundation of the liberal order is the post-war system of multilateral institutions built and maintained by the United States and its allies. Like trade, this too was already fragmenting long before Trump's ascension. The large UN-based multilaterals that formed the core of the post-war order are no longer the only game in global governance. Since the creation of the UN system in the 1940 os there has been a proliferation of regional and plurilateral arrangements, private initiatives, and various forms of partnership involving governments, private parties, and civil society actors in such areas as security, climate change, and human rights-many of which were neither the product of U.S. leadership nor beholden to American purpose. Here again, as with trade, the Trump administration is following a trend already in motion, seeking to further sideline the traditional, long-standing liberal institutions. It has already indicated that the United States will place greater stress on bilateral deals based on a stricter and more direct reciprocity, rather than rely on multilateralism.

In this vein, although alliances are instruments of realpolitik and power politics, U.S. liberal internationalists have long viewed the global network of U.S. alliances as the bedrock of the liberal order's provision of public goods. Trump is of course not the first American leader to call for U.S. allies to do more for their own defense, but his approach is much more than the usual "burden-sharing" talk 
of past presidents, such as Nixon and Reagan. Trump projects a fundamental lack of faith in the strategic and normative utility of U.S. alliances. He is also the first president who has explicitly warned allies of the withdrawal of U.S. protection in the event that they do not comply with his demands. He may not carry out his threats, but his stance itself further undermines the credibility of the liberal order.

The third element of the liberal order is the growth of democracy. The global democratic revolution known as the Third Wave saw the number of democracies nearly double after the end of the cold war. However, the trend had already peaked by $2000,{ }^{9}$ and it faced further setbacks with the unfulfilled promise of the Arab Spring and reversals and backslidings in Egypt and Thailand. Against this rather dismal backdrop, there is now a real possibility that Trump's victory might encourage authoritarianism around the world. Indeed, Trump's victory is reassuring not only to anti-democratic leaders outside the West-such as Russia's Vladimir Putin, Turkey's Recep Tayyip Erdoğan, and Hungary's Viktor Orbán-but also to far-right movements in the West, such as those led by the Netherlands' Geert Wilders, Italy's Matteo Salvini, Britain's Nigel Farage, and France's Marine Le Pen (who received an impressive 33.4 percent in the recent French presidential elections). Whether such an authoritarian wave will materialize remains to be seen, but there is little question that Trump's victory has given democracy a bad name. "Democracy the loser in U.S. Vote," declared the China Daily, which criticized the level of personal attacks and "nasty aspects" of American-style democracy during the long and brutal presidential election campaign. ${ }^{10}$

The fourth element is liberal values, which have suffered greatly since the election of Trump. As noted by Volker Perthes, director of the German Institute of International and Security Affairs, Trump's victory "represents a hard knock for the West's normative bedrock of liberalism." ${ }^{11}$ It has also dented America's soft power, which depends much on the attractiveness of its domestic politics, culture, and institutions. People around the world are unlikely to forget Trump's attack on the Hispanic judge in California, which fellow Republican and House Speaker Paul Ryan described as a "textbook case of racism," or his attack on the parents of Gold Star U.S. Army Captain Humayun Khan, who died from a car bomb in Iraq after ordering subordinates to stand back while he inspected the vehicle. As this soft power continues to erode, the influence of the liberal order will continue to wane. 


\section{The Emerging Powers}

It is ironic that while the founders of liberal order are retreating (at least temporarily), and the order itself is fraying at the edges, some of the powers, especially China, that are supposed to challenge it are offering support, albeit qualified and potentially short-term. In his speech at Davos in January 2017, Chinese President Xi Jinping came out strongly against protectionism, and Chinese policymakers (such as He Yafei, a former Vice Minister for Foreign Affairs) speak of their country leading a new wave of globalization. ${ }^{12}$ This should not be surprising, as public opinion in China and India are strongly in favor of globalization. A few weeks before the November 2016 U.S. presidential election, a Pew Survey reported that 60 percent of Chinese respondents and 52 percent of Indians agreed that involvement in the global economy is a positive thing, compared to only 44 percent of Americans. ${ }^{13}$ Among the BRICS, Russia has been a loser in globalization, and hence may be least interested among them in preserving the liberal order.

Moreover, the BRICS are not in a position to exploit the crisis in the liberal order through concerted action even if they so desired, as some of them, such as Brazil, South Africa, and Russia, are themselves in considerable economic and political distress. The GDP growth of the five BRICS nations slowed from an average of 9 percent annually in 2010 to about 4 percent in 2015 . Investment growth slowed from 16 percent in 2010 to 5 percent in $2014 .{ }^{14} \mathrm{In}$ 2015, Goldman Sachs closed its BRICS investment fund, which had lost 88 percent of its assets since its 2010 peak. ${ }^{15}$ These economic setbacks will hinder any attempt to formulate some new order. At the same time, political challenges also abound. China-India tensions over the border dispute in the Doklam region, as well as China's opposition both to India's bid to join the Nuclear Suppliers Group and its attempt to add the chief of the anti-India terrorist group Jaish-e-Mohammad to the UN's terrorist list, demonstrate that the two arguably most important BRICS nations, given their vast economies and populations, do not share a common vision of world order. Further, although India is a key member of the China-initiated multilateral Asian Infrastructure Investment Bank (AIIB), it is opposed to China's One Belt, One Road (OBOR) initiative ${ }^{16}$ (and especially the China-Pakistan Corridor) because it undercuts Indian influence in South Asia.

China and India also suffer from problems of legitimacy and support in their own respective neighborhoods, further constraining their potential to take a greater role in world order. China is embroiled in bitter territorial disputes with Japan over 
islands in the East China Sea, and with Vietnam, the Philippines, and others over islands in the South China Sea. Meanwhile, India's relations with its own South Asian neighbors remain difficult, and could worsen due to growing Chinese aid to neighbors such as Pakistan, Nepal, and Sri Lanka as part of the OBOR initiative.

Domestic political problems (in Brazil and South Africa) and dependence on global trade (especially for China and India) ensure that the putative challengers to the liberal order may hold back or even offer greater support to that order at least in the short term - as Xi Jinping did in Davos. ${ }^{17}$ Nevertheless, it would be a mistake to assume that the emerging powers would have the same stake in the liberal order as the West simply because they have benefited, and are still benefiting, from it. Without concrete progress in meeting their demand for reform of the existing international institutions to give them more voice and influence, the rising powers will be suspicious of accepting any new schema devised in the West for preserving the liberal order. At the same time, they still have to co-exist with the West, which itself has to negotiate accommodation with them in order to salvage aspects of the liberal order. This interplay is the inexorable logic driving us toward what I call a "multiplex world."

\section{Multiplexity, Not Multipolarity}

Many pundits see the emerging world order as a return to multipolarity, but this is misleading. There are at least five major differences between prewar multipolarity and the emerging twenty-first-century world order. First, prewar multipolarity was largely a world of empires and colonies. The primary actors in world politics were the great powers, and those were mainly European, though the United States and Japan joined the club in the latter part of the nineteenth century. In contrast, the contemporary world is marked by a multiplicity of actors that matter. These are not only great powers, and not even just states, but also international and regional institutions, corporations, transnational nongovernmental organizations, social movements, transnational criminal and terrorist groups, and so on.

Second, the nature of economic interdependence today is denser, consisting of trade, finance, and global production networks and supply chains, whereas prewar multipolarity was mainly trade-based.

Third, contemporary economic interdependence is more global compared to that in the nineteenth century, when it was mostly intra-European, with the rest of the world in a situation of dependence on the European empires. 
Fourth, there is far greater density of relatively durable international and regional institutions today, whereas pre-World War I Europe had only onethe defunct European Concert of Powers-and the interwar period only had the short-lived and failed League of Nations.

Fifth, challenges to order and stability have become more complex. The traditional challenge to world order, interstate conflict, has declined steadily since World War II and now stands at a negligible level. Meanwhile, intrastate conflicts and transnational challenges have grown considerably. Arguably, the biggest threat to the national security of many countries today comes not from another state but from a terrorist network. Moreover, issues such as climate change, human trafficking, drugs, and pandemics do not respect national boundaries and are magnified by interdependence and globalization, further complicating the mosaic of security challenges facing the twenty-first-century world.

The emerging world order is thus not a multipolar world, but a multiplex world. ${ }^{18}$ It is a world of multiple modernities, where Western liberal modernity (and its preferred pathways to economic development and governance) is only a part of what is on offer. A multiplex world is like a multiplex cinema-one that gives its audience a choice of various movies, actors, directors, and plots all under the same roof. Trump and Brexit have shown that there are serious variations and differences in the script of world order even within the West-not just between the West and the rest, as is commonly assumed. At the same time, a multiplex world is a world of interconnectedness and interdependence. It is not a singular global order, liberal or otherwise, but a complex of crosscutting, if not competing, international orders and globalisms.

A multiplex world is not defined by the hegemony of any single nation or idea. This does not necessarily mean the United States is in decline-this is still arguable. But it does mean that the United States is no longer in a position to create the rules and dominate the institutions of global governance and world order in the manner it had for much of the post-World War II period. And while elements of the old liberal order will survive, they will have to accommodate new actors and approaches that do not bend to America's commands and preferences.

\section{Crosscutting Globalisms, Not Liberal Hegemony}

It is wrong to say that globalization is over. Instead, in a multiplex world it will take, and is already taking, a different form. Globalization may become less driven 
by trade and more by developmental concerns. This might give more space to the initiatives of the emerging powers, which tend to focus more on infrastructure than on free trade. Thus, the new globalization could well be led less by the West and more by the East, especially China and India, as it had been for a thousand years before European colonialism. On its own, China may not be able to lead globalization outright, but it has the potential to reshape it with initiatives like the One Belt, One Road strategy and the AIIB.

Moreover, the new globalization will be anchored more by South-South linkages rather than North-South ones. This is already happening: According to the United Nations Development Programme, the South has increased its share of global output from one third in 1990 to almost a half today, and it has increased its share of world merchandise trade from 25 percent in 1980 to 47 percent in 2010. ${ }^{19}$ And South-South trade jumped from less than 8 percent of world merchandise trade in 1980 to about 25 percent in $2014 .{ }^{20}$ According to the United Nations Conference on Trade and Development, South-South flows in foreign direct investment now constitute over a third of global flows. ${ }^{21}$ These trends could reshape globalization.

Due to the prominence of China and other emerging powers, the new globalization might also be more respectful of sovereignty, especially compared to the Western-led globalization during the nineteenth and twentieth centuries, which has been associated with colonialism and direct and indirect military intervention to secure Western economic and strategic interests (a long list of examples would include the Suez and numerous interventions in Latin America). This is not to say that emerging powers do not use force or violate sovereignty. With its growing overseas investments, China will be tempted to abandon its professed policy of noninterference and to use force or coercion in support of its economic and strategic goals. But in line with the outlooks of the emerging powers, the new globalization is likely to be more economic and less political or ideological (especially compared to the West's promotion of democracy and human rights).

\section{G-Plus, Not G-Zero, Governance}

Many of Trump's stated policy positions suggest a nationalist, inward-looking U.S. foreign policy. His policies on trade and security are undermining global institutions, such as the World Trade Organization and the United Nations, and disrupting climate change negotiations. In many ways, this may push the system of global governance to be even less U.S.- and Western-centric. But here, too, as noted 
earlier, the post-war architecture of global governance was already moving in that direction. Global governance has already begun accommodating the growing roles of private bodies (corporations, foundations, etc.), civil society groups, and regional arrangements, thus reducing the position of formal intergovernmental organizations. And the emerging powers have already been clamoring for a greater voice and leadership in existing institutions while also creating new global and regional mechanisms, such as the BRICS-initiated New Development Bank and Contingent Reserve Arrangement (a financial mechanism), the AIIB, China's OBOR and its Conference on Interaction and Confidence-Building Measures in Asia mechanism, and India's own plans for infrastructure development in South Asia, to name a few. And while the demand for global governance will remain, the architecture will continue to fragment and decenter, confirming the onset of the multiplex world.

The maintenance of world order depends on regional orders. As Henry Kissinger argues, "The contemporary quest for world order will require a coherent strategy to establish a concept of order within the various regions and to relate these regional orders to one another." 22 Yet developing such inclusive, open regional orders is a critical challenge. This would require creating new regional mechanisms and supporting those that already exist but are constrained by a lack of resources. While some liberal thinkers see regionalism (not including the European Union) as a threat to world order, there are many regional initiatives that, if recognized and strengthened, could actually support world order. For example, ASEAN + 3's Chiang Mai initiative on finance has allowed those countries to better cope with short-term liquidity problems, supplementing the existing capacity of the International Monetary Fund. ${ }^{23}$ As another example, though the Obama administration feared the Chinese-inspired AIIB would be a competitor to the World Bank, its structure and rules mimic those of established multilateral institutions, and its management includes persons from Western countries. Thus, it is more likely to complement rather than compete with the World Bank or Asian Development Bank. In a fragmented and pluralistic world, exploring local and regional initiatives in diverse issue areas that complement older but fragmenting global institutions could be one of the most promising way to build world order in the twenty-first century.

A multiplex world will not be free from disorder, but it is also not necessarily doomed to be what Ian Bremmer and Nouriel Roubini call a G-Zero World-“one in which no single country or bloc of countries has the political and economic 
leverage - or the will-to drive a truly international agenda"24 - simply because of the loss of a predominant U.S. leadership role. Leadership-sharing between the Western powers and the emerging powers is more attainable than (hard) powersharing. A world less dependent on U.S. leadership-but without a complete U.S. retreat into isolationism-will still find ways to cooperate. It will still come together in crisis, as happened at the G-20 summit after the 2008 global financial crisis, or to combat common perils, as happened with the 2015 Paris Agreement on climate change. ${ }^{25}$ The latter was made possible not because of proactive U.S. leadership but because of common understanding among the Western nations, the emerging powers (led by China), and civil society groups. Importantly, the agreement avoided the traditional Western legalistic sanction-based approach in favor of a softer, voluntaristic approach that is characteristic of the Association of Southeast Asian Nations.

A multiplex world is a G-Plus world, featuring established and emerging powers, global and regional institutions and actors, states, social movements, corporations, private foundations, and various kinds of partnerships among them.

\section{The Stability of a Multiplex World}

There are several things that should be kept in mind by the international community in general and the Western nations in particular to help manage the transition to a multiplex world.

First, stop pining for the return of liberal hegemony, by which I mean the postWorld War II world order created and dominated by the United States and centered around Western interests, values, and institutions. That order might have delivered much good (as well as lots of bad) to the world, and some of its institutions (such as the UN system) will continue, but the particular historical circumstances behind the rise of liberal hegemony are gone. The global power shift is for real and here to stay.

Second, unless and until the Trump administration radically changes course or is replaced, prepare to live without significant U.S. support for multilateralism. Under Trump, this support might come selectively and sparingly, but its absence should not deter international cooperation if other major players participate or offer support.

Third, the end of U.S. hegemony does not equal the "return of anarchy," if anarchy implies the end of global cooperation, as some worry. ${ }^{26}$ Progress in global 
governance was never linear to start with, nor was there ever any consensus that global governance is a good thing. Demand for global governance has and will continue to be varied depending on the issue area. Such demand is driven by a mix of strategic, functional, and normative motives as well as a domestic political calculus. ${ }^{27}$ While the normative and domestic motivations may be declining among Western states, the functional and strategic motivations might yet drive demand for global governance in several areas, including climate change and transnational security.

Fourth, despite claims about the world being "on fire," there are also many success stories of growth and stability in the world. ${ }^{28}$ When it comes to international stability, there is both good and bad news. Some forms of international violence, such as interstate wars, are on a long-term decline. ${ }^{29}$ For all its media coverage and obvious tragedy, terrorism poses a largely concentrated, localized threat. In 2015, for example, only five countries-Afghanistan, Iraq, Nigeria, Pakistan, and Syriaaccounted for 72 percent of deaths from terrorism worldwide. Also notable, just four groups were responsible for 74 percent of all these deaths: the self-proclaimed Islamic State, Boko Haram, the Taliban, and al-Qaeda. ${ }^{30}$ Moreover, many of the signs of "anarchy" today, including death tolls in the Middle East, are the result of failed but avoidable policies pursued by the United States and its key Western allies. Examples here might include the 2003 U.S. invasion of Iraq, or the 2011 Anglo-French operation in Libya to effect regime change (thus abusing UN Security Council Resolution 1973, which was meant for civilian protection). Further, as some have argued, the Libya case may have been partly responsible for the subsequent failure to intervene in Syria. Estimates published by the International Institute for Strategic Studies found that out of the total 180,000 conflict-related fatalities worldwide in 2014, Iraq and Syria accounted for nearly half. ${ }^{31}$ Learning from these mistakes is more important to the future of world order than yearning to bring back liberal hegemony.

Fifth, give due credit to the contribution of non-Western actors to the marketplace of ideas for global cooperation. Latin American countries championed human rights before the Universal Declaration of Human Rights and had developed a tradition of regional norm and institution building before the EU was conceived. $^{32}$ The East Asian countries, led by Japan, pioneered a path out of postcolonial dependency and underdevelopment. The UN Convention on the Law of the Sea had much to do with the leadership of Southeast Asian diplomats. The ideas of human development and human security were conceived by 
Pakistani economist Mahbub ul Haq, while the Responsibility to Protect concept was to a large extent an African contribution.

Sixth, encourage pragmatic globalism in place of ideologically-charged liberal internationalism, a term that is deeply associated with Western hegemony and hypocrisy. History provides many examples of practical, non-ideological, issuebased cooperation among nations of diverse political composition to uphold international stability.

Seventh, embrace G-Plus global governance. The growing complexity of global governance is inevitable due to the proliferation of a variety of new actors and transnational issue areas. It is impossible for the state-centric bureaucratic institutions crafted in the 1940 s to cope with these changes. These institutions should welcome the proliferation of "demanders" of global governance and learn to work with them, avoiding duplication of resources. The ongoing fragmentation in global governance creates new opportunities for closer partnership between intergovernmental institutions, civil society, and the private sector.

Eighth, take regional powers and regionalism seriously. Regions are crucial sites for both conflict and cooperation. In considering ways to develop a new world order, one should not focus too much on the big emerging powers while neglecting the role of other regional powers in the developing world, such as Indonesia, Nigeria, and Turkey. Not all forms of regionalism are harmful to global cooperation; indeed, they may contribute to it. Many regional organizations share normative concerns about peace and justice and deserve their space in any meaningful scheme for global order. The traditional liberal universalist tendency to associate regionalism with spheres of influence or power balancing is misplaced, since many examples of regionalism today are open, interactive, and inclusive.

In sum, the stability of a multiplex world will require many Western nations to give up their free-riding on the United States and accept shared leadership with the rising and regional powers. It will require greater partnership between global and regional bodies, as well as public, private, and civil society groups. A G-Plus world requires a genuinely reformed system of global governance that accords sincere recognition to the voices and aspirations of all. America and its Western allies must give up exclusive privileges such as the French leadership of the IMF, American presidency of the World Bank, and Japanese presidency of the Asian Development Bank in return for the trust and cooperation of the rest. 


\section{A New Vocabulary of International Relations}

The complexity of international politics today calls for a greater questioning of the existing theories and vocabulary of international relations, especially of liberalism and realism. Liberals often profess a monopoly over all "good things" in international life, such as rationality, respect for human dignity, good governance, free trade, and rule-based order, and they trace the origins of these goods exclusively from Western civilization. Yet these ideas and practices can be found in other, non-European civilizations, including but not limited to Islamic, Chinese, and Indian. Liberal theory has shown little acknowledgement of the multiple sources of and contributions to the development of its ideas and practices. As a result, liberalism is seen today as asking and expecting "the rest" to follow principles that it claims have been solely developed in the West, even as the leading liberal Western nations grossly violate them. With liberalism now under challenge at home, it will be even harder to sell it to the rest of the world.

When facing the future, while liberals remain in denial, realists return to the past. Instead of seeking fresh ideas to understand and explain change in world politics, they keep rehashing notions like multipolarity (or the general theory that international stability depends mainly on polarity or the distribution of power) or the Thucydides's Trap to describe the present or emerging world order. ${ }^{33}$ This is a misapplication of history. The world today is a far cry from the nineteenth-century multipolar era; it is even more distant from the self-styled and limited geopolitics of the Greek city-states.

The era of liberal hegemony is past. The liberal international order will be just one of many crosscutting systems, and it will have to compete or enmesh with other ideas in a world of growing complexity and interconnectedness. International relations scholars should be wary of conventional wisdom and be open to new concepts and theories, and hence to new possibilities of world order that have no precedent in history. Keohane was right: A hegemon is neither necessary nor sufficient for global order-and neither, it turns out, is an unchallenged liberal ideology. In a multiplex world, scholars and practitioners alike will have to embrace the complexities of this new system. The future may very well depend on it.

\section{NOTES}

${ }^{1}$ Robert O. Keohane, After Hegemony: Cooperation and Discord in the World Political Economy (Princeton: Princeton University Press, 1984), p. 46. 
${ }^{2}$ A prime example is the special issue under the cover heading "Out of Order? The Future of the International System," Foreign Affairs 96, no. 1 (January/February 2017), www.foreignaffairs. com/issues/2017/96/1. See also Anne-Marie Slaughter, "The Return of Anarchy?" Journal of International Affairs, March 15, 2017, jia.sipa.columbia.edu/return-anarchy.

3 Amitav Acharya, The End of American World Order (Cambridge: Polity, 2014), p. 37.

${ }^{4}$ Joseph S. Nye, "Will the Liberal Order Survive? The History of an Idea," Foreign Affairs 96, no. 1 (January/February 2017).

5 Barry Eichengreen, "Globalization's Last Gasp," Project Syndicate, November 17, 2016, www.projectsyndicate.org/commentary/growth-before-globalization-by-barry-eichengreen-2016-11?barrier=accessreg.

6 This term refers to the documented phenomenon of when the rapidly growing economy of a country stagnates after reaching a per capita income level of roughly $\$ 10,000$ to $\$ 15,000$ as it loses the initial advantages that had led to high growth, such as abundant cheap labor and high investment rates, to low-wage competitors.

7 Edward Alden, "The Biggest Issue That Carried Trump to Victory," Fortune, November 10, 2016, fortune.com/2016/11/10/trump-voters-free-trade-globalization/.

8 "7 Point Plan To Rebuild the American Economy by Fighting for Free Trade," www.facebook. com/notes/the-2016-committee/donald-j-trumps-vision/1251246731604221/.

9 John Micklethwait and Adrian Wooldridge, The Fourth Revolution: The Global Race to Reinvent the State (New York: Penguin Press, 2014).

10 "Democracy the Loser in U.S. Vote," China Daily (USA), November 9, 2016, usa.chinadaily.com. cn/opinion/2016-11/o9/content_27317869.htm.

${ }^{11}$ Volker Perthes, "President Trump and International Relations," Point of View, Stiftung Wissenschaft und Politik, German Institute for International and Security Affairs, November 18, 2016, www. swp-berlin.org/en/point-of-view/president-trump-and-international-relations/.

${ }^{12}$ He Yafei, "China's Role in Steering the Future of Globalisation," Telegraph, May 10, 2017, www.telegraph.co.uk/news/world/china-watch/politics/role-in-steering-globalisation/; Zheng Bijian (former permanent Vice-President of the Central Party School), "China's 'One Belt, One Road' Plan Marks the Next Phase of Globalization," Huffington Post, May 18, 2017, www.huffingtonpost.com/entry/chinaone-belt-one-road_us_591c6b41e4boed14cddb4527.

13 Bruce Stokes, "Unlike the West, India and China Embrace Globalization," Yale Global Online, October 18, 2016, yaleglobal.yale.edu/content/unlike-west-india-and-china-embrace-globalization.

${ }^{14}$ World Bank Global Macroeconomics Team, "Global Weekly: Sources of the Growth Slowdown in BRICS," January 11, 2016, blogs.worldbank.org/prospects/global-weekly-sources-growth-slowdown-brics.

15 Suzanne Nossel, “The World's Rising Powers Have Fallen," Foreign Policy, July 6, 2016, foreignpolicy. com/2016/07/06/brics-brazil-india-russia-china-south-africa-economics-recession/.

16 The OBOR, also known as the Belt and Road Initiative (BRI), is a massive Chinese economic aid and investment program worth over a trillion U.S. dollars over the next decade. Launched by President Xi Jinping in 2013, it focuses on infrastructure development in Eurasia and beyond. China's motives behind the initiative are both economic (such as expanding markets for its surplus production capacity, new business for Chinese companies, and promoting the economic development of its western provinces), and strategic, especially enhancing Chinese influence in the region and the world. See Scott Cendrowski, "Inside China's Global Spending Spree," Fortune, December 12, 2016, fortune. com/china-belt-road-investment/.

17 Amitav Acharya, "Emerging Powers Can Be Saviours of the Global Liberal Order," Financial Times, January 18, 2017.

18 Acharya, End of American World Order. Interestingly, a recent essay in Foreign Affairs also argues for developing a "mixed order" to cope with a "pluralistic world." See Michael J. Mazarr, "The Once and Future Order: What Comes After Hegemony?” Foreign Affairs 96, no. 1 (January/February 2017).

${ }^{19}$ United Nations Development Programme (UNDP), Human Development Report 2013. The Rise of the South: Human Progress in a Diverse World (New York: UNDP, 2013), p. 2.

${ }^{20}$ Ibid; Joakim Reiter, Deputy Secretary-General of United Nations Conference on Trade and Development (UNCTAD), "UNCTAD and South-South Cooperation," March 10, 2016.

${ }^{21}$ United Nations Conference on Trade and Development, World Investment Report 2015 (Geneva: United Nations, 2015), pp. 5, 8-9, unctad.org/en/PublicationsLibrary/wir2015_en.pdf.

${ }^{22}$ Henry Kissinger, "Henry Kissinger on the Assembly of a New World Order," Wall Street Journal, August 29, 2014, www.wsj.com/articles/henry-kissinger-on-the-assembly-of-a-new-world-order-1409328075.

${ }^{23}$ ASEAN +3 refers to the Association of Southeast Asian Nations plus China, Japan, and South Korea.

${ }^{24}$ Ian Bremmer and Nouriel Roubini, "A G-Zero World," Foreign Affairs 90, no. 2 (March/April 2011), www.foreignaffairs.com/articles/2011-01-31/g-zero-world. 
${ }_{25}$ On June 1, 2017, Trump announced the withdrawal of the United States from the Paris Agreement. However, far from signaling the collapse of the agreement, the reaction to U.S. withdrawal perfectly illustrates the dynamics of the multiplex world, where global cooperation on critical challenges does not necessarily rely on a leading power. No other country followed the United States; and at a meeting in Hamburg in July 2017, the other nineteen members of the G-20 reaffirmed their "strong commitment" to the Agreement, calling it "irreversible." Trump's decision paradoxically also prompted a wave of domestic support for the Agreement, including from U.S. businesses, states, and cities, which are especially crucial to climate action. See Oliver Milman, "G2o leaders' statement on climate change highlights rift with US," The Guardian, July 8, 2017, www.theguardian.com/world/2017/jul/ 08/g20-climate-change-leaders-statement-paris-agreement.

${ }^{26}$ Slaughter, "The Return of Anarchy?"

27 For a detailed discussion and debate, see Amitav Acharya, ed., Why Govern? Rethinking Demand and Progress in Global Governance (Cambridge, U.K.: Cambridge University Press, 2016).

${ }^{28}$ Fareed Zakaria, "Global Success Stories," Washington Post, August 7, 2014, www.washingtonpost. com/opinions/fareed-zakaria-global-success-stories/2014/08/07/9197aoa6-1e54-11e4-ae54-ocfe1f974f8a_story.html?utm_term $=.6 \mathrm{f} 237 \mathrm{df} 6 \mathrm{eo} 8 \mathrm{a}$.

29 Therése Pettersson and Peter Wallensteen, “Armed conflicts, 1946-2014," Journal of Peace Research 52, no.4 (2015), p. 537.

${ }^{30}$ Global Terrorism Index 2016 (Sydney and New York: Institute for Economics and Peace, 2016), p.3, economicsandpeace.org/wp-content/uploads/2016/11/Global-Terrorism-Index-2016.2.pdf. This data is derived from the Global Terrorism Database of the National Consortium for the Study of Terrorism and Responses to Terrorism (START), a Department of Homeland Security Center of Excellence at the University of Maryland.

${ }^{31}$ The International Institute for Strategic Studies, The IISS Armed Conflict Survey 2015, Press Statement, Arundel House, London, May 20, 2015, pp.1-2, www.iiss.org/en/about\%2ous/press\%2oroom/press\% 2oreleases/press\%2oreleases/archive/2015-4feg/may-6219/armed-conflict-survey-2015-press-statementaobe.

32 These Latin American initiatives included the Inter-American Conference on Problems of War and Peace, attended by nineteen Latin American nations and held in Mexico City, February 21-March 8, 1945 (the Chapultepec Conference). Three years later, twenty Latin American and Caribbean countries as well as the United States signed the American Declaration of Rights and Duties of Man at Bogota, Colombia, in April 1948- seven months before the passage of the Universal Declaration of Human Rights on December 10, 1948. See Kathryn Sikkink, "Human Rights," in Why Govern, ed. Amitav Acharya (Cambridge: Cambridge University Press, 2016) pp.125-133. See also Amitav Acharya. "'Idea-Shift': How Ideas from the Rest Are Reshaping Global Order," Third World Quarterly 37, no. 7 (2016), pp. 1156-170; "Principles from the Periphery: The Neglected Southern Sources of Global Norms," Global Governance 20, no. 3 (2014); and "The UN and the Global South, 1945 and 2015: Past As Prelude?" Third World Quarterly 37, no. 7 (2016).

${ }^{33}$ Graham Allison, Destined for War: Can America and China Escape Thucydides's Trap? (Boston: Houghton Mifflin Harcourt, 2017). Although Allison popularized the phrase "Thucydides's Trap," the underlying logic of the term reflects realist theories of international relations, especially "power transition" theory, which is precisely about how a rising power and a status-quo power might get into conflict. 